\title{
Learning Media in Indonesia Higher Education in Industry 4.0: Case Study
}

\author{
Rizal1 $^{{ }^{*}}$, Misnasanti ${ }^{2}$, Syahrial Shaddiq ${ }^{3}$, Ramadhani ${ }^{4}$, Feri Wagiono ${ }^{5}$ \\ ,Universitas Negeri Yogyakrta, Indonesia \\ 2Universitas Islam Negeri Antarsari Banjarmasin, Indonesia \\ ${ }^{3}$ Universitas Islam Indonesia, Indonesia \\ ${ }^{4}$ Universitas Muhammadiyah Yogyakarta, Indonesia \\ 5Universitas Palangka Raya, Indonesia
}

Corresponding Author: Rizal @ rizal.2019@student.uny.ac.id*

\section{ABSTRACT}

\section{ARTICLE INFO \\ Article history: \\ Received \\ July 03, 2020 \\ Revised \\ November 21, 2020 \\ Accepted \\ November 25,}

2020

How to cite
The aims of this research was to fill the theoretical and empirical gaps about the case study with regard to learning media in Indonesia's higher education in industry 4.0 and society 5.0 era. This research used qualitative methods. Data collection techniques used interviews, observations, and documentation. The results of this study revealed tht virtual learning (VL) media ws an effective learning media in Indonesian higher education in industry 4.0 and society 5.0. Therefore, the use of relevant learning models was in line with the times, and the use of more flexible VL media was a strategy to enhance educational quality in the Unitary State of the Republic of Indonesia.

Keywords: Learning Media, Education in Industry 4.0, Higher Education Rizal, R., \& Misnasanti, M., Shaddiq, S., Ramdhani, R., \& Wagiono, F. (2020). Learning Media in Indonesia Higher Education in Industry 4.0: Case Study. IJoASER (International Journal on Advanced Science, Education, and Religion), 3(3). 127-134 https://doi.org/10.33648/ijoaser.v3i3.62

Journal Homepage https://ojs.staialfurqan.ac.id/IJoASER/

This is an open access article under the CC BY SA license

\section{INTRODUCTION}

Along with the development of the information system, information technology, information science, and information engineering in the world, Globalization has entered a new era, namely the industrial revolution 4.0according to the world industrial revolutionthe revolution has entered stage four. the 4.0 industrial revolution started in the 2012'sthrough internal engineering and the internet of things (IoT) asthe backbone of human movement and connectivityand machines (Asawa, 2018). Industry 4.0 is an era where the boundaries between humans and machines are almost non-existent (Ponidi, et al., 2020). The boundary between humans and technology is gone, in the world of higher education, especially in the western part of Indonesia, namely: the State University of Yogyakarta , the State University of Padang (UNP), and the Tanjungpura University and in the central part of Indonesia, namely: the Lambung Mangkurat University, the Islamic University of Kalimantan Muhammad Arsyad Al Banjari,the State Islamic University of Antasari and the Indonesian Moslem University. In some of these colleges virtual learning technology is being applied. This certainly greatly affect the dynamics of the development of higher education in Indonesia. 
The important thing to examine in this case study is how much influence virtual learning has on human development in the world of higher education, especially in the Republic of Indonesia. In this regard, high tech-sensors as supporting technology have been developed learning media. Electronic marketing as a way and strategy to attract learning media (Ramadhani et al., 2021). Electronic governance is a good governance strategy that can be applied to smart learning media in Indonesia (Saputra et al., 2020). In addition, micro-hydro and solar water pump can be an alternative source of new and renewable energy (NRE) to develop learning media based NRE (Shaddiq et al., 2012; Kusuma et al., 2016).

The potential of rivers in the new capital city is very potential, therefore it is very important in the future to implement environmentally friendly micro-hydro [Shaddiq et al., 2012]. Distributed generation (DG) as a new and renewable energy source based on wind, water, sunlight, and so on can be a solution and provide novelty compared to conventional generators to develop learning media-based DG (Shaddiq et al., 2016). The problem that occurs in learning media in Indonesian Higher Education is the unequal quality of development in each area (Suhono \& Sari, 2020). In addition, it is necessary to develop new and renewable energies, for example, wind turbines for energy sources for development (Shaddiq, 2013). Likewise, in terms of education it is not evenly distributed and still needs innovation in many sectors. Some of the innovations that have been offered are Learning Media, where this innovation is still experiencing support and criticism in the community. Many related studies have discussed this issue but in this case study, it has a specific location and targets universities that have various backgrounds, where they are universities that have different quality of development. As we know mobile learning as a learning technology in school and campuses is the key to the advancement of e-learning based education 4.0 and industry 4.0 (Wagiono et al., 2020; Fadilurrahman et al., 2019). As we know education is a fundamental thing, there is a need for innovation that can be a wheel to accelerate the quality of education in Indonesia, learning media is something that we definitely face and use so that through research it can improve the quality of education, especially in terms of learning media.

Learning media are all tools and materials that can be used for educational purposes, such as radio, television, books, newspapers, magazines and so on (Yunita, 2020). Learning media can be interpreted as something that can carry Rossi \& Breidle in Sanjaya (2010). information and knowledge in the interaction that takes place between educators and students (Mahmud \& Idham, 2017). this technology has made many people no longer difficult to obtain various information, knowledge, and entertainment. Important events and events that occurred in all corners of the world can be witnessed easily and quickly (Busyaeri et al., 2016), this makes the vast world seem to be narrow and almost do not have a dividing wall in between. Video learning is also an appropriate step to answer various problems of education in this country, this is proven by the results of research with visual learning that can increase memory by $14 \%$ to $38 \%$. This research also shows up to a $200 \%$ improvement in vocabulary when taught visually. Even the time needed to deliver a concept is reduced by $40 \%$ to increase verbal presentation (Zaenal, 2012).

In the current era of globalization, a generation that is dependent on devices, or a generation better known as the millennial generation, is more like a supporting device. This generation can also be called the device generation or generation which means a generation whose lives always intersect with equipment that contains 
elements of information technology, so that it has come together like a part that is difficult to separate (Cao et al., 2019).

According to Emi (2015), there are a number of studies on the impact and use of the internet which have the impact that the internet is the main source of learning and can eliminate loneliness and can spend time as a habit and do things with other people. There are many benefits that can be obtained by someone from the internet, especially in the process of communication and information gathering for the entire internet user community (Emi, 2015). The advantages and disadvantages of learning in the form of video, namely: the advantages of video media that present concrete learning objects or learning messages realistically, so it is very good for adding to the learning experience, has its own charm and can be a trigger or motivate learners to learn. both to take psychomotor learning objectives, can reduce learning boredom, especially if joining lecture teaching techniques and discussion of the problems displayed, increase memory retention or retention of learning objects that learners learn, are portable and easy, whereas MediaVideo's weaknesses are: to provide them with expensive costs, dependent on energy so that it cannot be turned on anywhere.

\section{METHOD}

This research methodology uses qualitative methods with case study for the type of this researchtype of research that produces descriptive data in the form of words that are written or oral form people and observable behavior. Researchers describe the phenomena and objects (Moser \& Korstjens, 2018). Collecting data using collected through interviews with students in higher education in the Special Region of Yogyakarta and South Boneo, the unit of analysis uses a sample of individuals in higher education, especially bachelor students in classes at the universities, such as: the State University of Yogyakarta (UNY), the State Islamic University of Antasari (UIN Antasari) Banjarmasin, the Lambung Mangkurat University (ULM) Banjarmasin, the Islamic University of Kalimantan Muhammad Arsyad Al Banjari (UNISKA MAB) Banjarmasin, the Tanjungpura University (UNTAN) Pontianak, the Islamic Moslem University (UMI) Makassar, and the State University of Padang (UNP).

\section{RESULT AND DISCUSSION}

Researchers did the interview with some random students in higher education. They are from different universities in Indonesia. It consists of students in the Lambung Mangkurat University (ULM), the Yogyakarta State University (UNY), the State Islamic University of (UIN) Antasari Banjarmasin, the Islamic University of Kalimantan Muhammad Arsyad Al Banjari(UNISKA), the Tanjungpura University(UNTAN), the Islamic Moslem University(UMI), and the State University of Padang(UNP). The students are from different semesters and major. They have different opinions about learning strategy in Indonesia, especially on their campus.

Students from the Lambung Mangkurat University said that the learning strategy helps them much to understand the material. Every lecturer has its own strategy to teach in class. Sometimes they use e-learning to support it. Students can access certain materials and send their assignments through the university site. The university also provides the internet to make the students easier completing their duty. The learning is not applied conventionally. The students have to be more active and more creative. Lecturers and students are a partner where the lecture is as a facilitator for the students. So the learning process is more relax. 
A similar opinion comes from the State Islamic University of Antasari students. They said that some lecturers have used interesting learning strategies to make them understand the material well. Lecturers make students think critically, solving a problem by doing discussion and presentation. Students also have to be able to find material by themselves. The lecturers also sometimes give students some motivation to keep their enthusiasm. Although there are some lecturers still dominant in learning. Some students and alumni at Yogyakarta State University (UNY), we believe that adding video learning in teaching increases their level of understanding, namely students and students are better than just receiving material and assignments, but they do not agree to turn all learning into video learning because they think that there are still many students who find it difficult if they don't learn directly, they also find video learning helpful if used correctly.

A good learning strategy is also experienced by students at the UMI dan the UNP. It already follows technology development. Students can get their material by electronic learning (e-learning) and send their assignments online to reduce the using of paper, although some lecturers still ask students to print out their documents. The university holds a guest lecture by inviting speakers from abroad in order that students can enlarge their horizons. The university also updates its practice tools to make students easier to do their experiments.

The explanation above contrasts with the learning strategy in the Islamic University of Kalimantan Muhammad Arsyad Al Banjari. students feel unsatisfied with the learning strategy. It is less discussion and too fast learning. All lecturers just teach in the class, but they do not know whether the students can understand the material or not. They only know that they can teach their students until the material is finish. Sometimes, some lecturers read the material on the book without more explanation from them. It makes students lack knowledge. This is also supported by the opinion of the student at the Tanjungpura University who said that lecturers just teach in class after they question their students whether they understand or not, they did not do reflection to recheck their students' ability.

In order to understand the material well, students in the Lambung Mangkurat University hope that lecturers can teach them interestingly, not too monotone. With sometimes some lecturers just come into class just for teaching until the time is over. Unfortunately, they do it repeatedly. They should make students think critically to solve the problem. Lecturers should serve the material with exciting substance so students will not feel sleepy and bored. Students at the State Islamic University of Antasari give addition that in theory learning, it is better for the lecturer to make quizzes every week to remember the last lesson. Students have to observe every question because students chosen have to repeat the answer from their friends with their own language. It makes students learn automatically. It makes them feel nervous and entertain at the same time. Besides that, lecturers can give some motivation to enhance their enthusiasm for learning.

In line with the suggestions above, according to students in UMI and UNISKA $\mathrm{MAB}$, lecturers should give more explanations and examples to solve problems connected with the lesson. Therefore, students will master it and will not feel afraid to do the final test. Students at theTanjungpura University and the State University of Padang hope the lecturers can be good leaders for them wherever they are. The old lecturer can teach them well and talk less about the topic not related to the material. The University had better look for the qualified young lecturers to share knowledge related to scientific problems. Video learning is used as a learning medium for every 
level of education. From elementary school students to high education learners using videos in learning activities. In education, it is known as video learning terms or learning-based videos. Video learning is a delivery of knowledge or skill by using video. Videos to learn must have at least two elements of visual and audio. Visual elements are useful for providing a key source of information that is easily understood and synced with the audio elements used to parse the information. Learning to use your videos is more effective and efficient, easy to understand, and supports active learning and creating new experiences in learning.

Media becomes one of the main parts of learning. All college students have the same opinion that they can see the object in real. They not only imagine the theory in their mind but also can apply it directly. For instance, lecturers can use the special board to learn about the linear equation. It can build students' concepts well. Or students can do practice in the laboratory about the process of a volcanic eruption. Because it is really dangerous if students have to wait near the mountain until it explodes. It tells us that the media supports a lot to deliver knowledge. Nowadays, many lecturers use technology to teach a class, sometimes if they are very busy, they choose to teach in online learning. So they still can do their business while teaching. Although virtual learning has benefits and drawbacks, it still becomes the option of many lecturers nowadays. It makes learning easier. People can study wherever they are. They do not have to sit in class. Along with students who feel afraid to give questions directly to their lecturer, by virtual learning, they will not worry about it anymore. As well as it brings to a new opinion about virtual learning. At the present moment, virtual learning has been applied at school. For instance Ruangguru. It may make the quality of education in Indonesia can be at the same level. There is no limitation for students in a big city and a small city to have education because they can access it. If virtual learning is applied in higher education, will it work?

One of the students in UMI explains that virtual learning can be very useful for people who have a job but they also want to study because not everyone has time to come to class every day. The first obstacle to virtual learning is mood. Sometimes they only study when they have the assignment. Secondly, they cannot ask the lecturer directly if they have a problem to understand the material. So they have to solve by themselves or ask their friends to discuss it. However, people who want to study while working have to accept this way although in different ways.

Conversely, other students from the Lambung Mangkurat University disagree if virtual learning is applied to replace direct learning. They do not mind if virtual learning supports learning, but not as the main method. Because direct learning cannot be replaced however. There are some students who cannot understand the material without direct explanation. So it is still difficult to do virtual learning.

In the same way, one of the students at the Tanjungpura University said that the quality of education in each city is still at different levels. So, it is still hard to make the quality of education at the same level for all students in Indonesia. It is better to do the selection to recruit a new teacher. They have to select a qualified teacher in order that they have the same ability wherever they teach. For instance, we can see the education in Finland. It is hard to become a teacher because they have to be the best ten graduated students from the best universities in the world. Because of that, the quality of education in Finland is the same in each region. It is really different if we see the fact in Indonesia, many teachers in Indonesia are just until bachelor degree and with different ability. If they are not able to teach students well, how could Indonesia produce great alumnus. 
On the other hand, one of the students at the Islamic University of Kalimantan Muhammad Arsyad Al Banjari thinks that virtual leaning costs a lot while the income of every family is different in each region. They have to save money to pay for the internet. Besides the quality of the internet in an isolated area is still bad. Not all people also can use technology well. Furthermore, students in the State Islamic University of Antasari state that virtual learning makes them to not focus because it is uncontrolled well. Students could pretend to pay attention, but the fact is not. For that reason, virtual learning is still difficult to be applied.

Many suggestions from higher education students for better education in Indonesia. They mention advancing the infrastructure of education, the standard of education, the prosperity of teachers. Infrastructure is important to support students to study. it can be easier for them to do the experiment by using a complete facility. They can express their idea freely. The standard of education is needed in order that Indonesia is not always left behind other countries. Prosperous teachers can keep doing innovation in education. They can upgrade their ability to teach students. They have great enthusiasm to share their knowledge. So they can make great output as well.

Furthermore, all aspects must be changed, from learning methods to teacher eligibility. The right learning method will make students enjoy the learning process. They will not feel bored while studying. In addition, it is important to look at student talent. Don't force them to master all subjects. Maybe burying talent that can lead them to success. So, understanding student characters is very important for their bright future (Amri et al., 2020; Kristiawan et al, 2017). The problem solving that occurs in learning media in Indonesian higher education is the unequal quality of development in each area implemented. In addition, it is necessary to develop new and renewable energies, for example, wind turbines for energy sources for development implemented (Shaddiq, 2013). Likewise, in terms of education it is not evenly distributed and still needs innovation in many sectors. Some of the innovations that have been offered are Learning Media, where this innovation is still experiencing support and criticism in the community. Many related studies have discussed this issue but in this case study, it has a specific location and targets universities that have various backgrounds, where they are universities that have different quality of development. As we know mobile learning as a learning technology in school and campuses is the key to the advancement of e-learning based education 4.0 and industry 4.0 implemented. As we know education is a fundamental thing, there is a need for innovation that can be a wheel to accelerate the quality of education in Indonesia, learning media is something that we definitely face and use so that through research it can improve the quality of education, especially in terms of learning media implemented. This research can improve the quality of education, especially in terms of learning media implemented. The findings of our current study are that the locus emphasizes learning media in Indonesia higher education in industry 4.0, while previously emphasizing learning media in Indonesia higher education before industry 4.0.

\section{CONCLUSIONS}

Based on the results and discussion it can be concluded that VL has a positive and significant influence on learning media in Indonesian higher education in industry 4.0. Therefore, the use of relevant learning models in line with the times, and the use of more flexible VL media is a strategy to improve the quality of education in the Unitary Republic of Indonesia. 


\section{ACKNOWLEDGEMENTS}

We would like to acknowledgements to Allah Subhanahu Wa Ta'ala and the Prophet Muhammad Shallallahu 'Alaihi Wasallam.

\section{AUTHOR CONTRIBUTION STATEMENTS}

Rizal, R.; Misnasanti, M.; Shaddiq, S.; Ramadhani, R.; \& Wagiono, F.: Conceived and designed the experiments; Performed the experiments; Analyzed and interpreted the data; Contributed reagents, materials, analysis tools, or data; Wrote the article journal.

\section{REFERENCES}

Asawa, A. (2018). A study of Digital Disruption, Innovation, and Economic Transformation. Artificial Intelligence: The Star of the Digital Galaxy. Amazon Kindle: United States of America. Google Scholar

Amri, S., Ismawati, T., \& Armila, A. (2020). Studi Analisis Nilai Nilai Pendidikan Karakter Perspektif Syech Muhammad Khudhari Bek dalam Kitab Khulashah Nurul Yakin. Attractive: Innovative Education Journal, 2(2), 77-88 Google Scholar

Busyaeri, A., Udin, T., \& Zaenudin, A. (2016). Pengaruh penggunaan video pembelajaran terhadap peningkatan hasil belajar mapel IPA di MIN Kroya Cirebon. Jurnal Pendidikan Guru MI, 3((1)). Google Sholar

Cao, Y., Postareff, L., Lindblom-Ylänne, S., \& Toom, A. (2019). Teacher educators' approaches to teaching and connections with their perceptions of the closeness of their research and teaching. Teaching and Teacher Education, 85, 125-136. https:// doi.org/10.1016/j.tate.2019.06.013

Emi, M. (2015). Budaya Baca di Era Digital. Lembaga Ladang Kata. Google Scolar

Fadilurrahman, M., Ramadhani, R., Kurniawan, T., Misnasanti, M., \& Shaddiq, S. (2020). Systematic Literature Review of Disruption Era in Indonesia: The Resistance of Industrial Revolution 4.0. Journal of Robotics and Control (JRC), 2(1), 51-59. Google Scholar

Mahmud, S., \& Idham, M. (2017). Strategi Belajar-Mengajar. Syiah Kuala University Press. Google Scholar

Moser, A., \& Korstjens, I. (2018). Series: Practical guidance to qualitative research. Part 3: Sampling, data collection and analysis. European Journal of General Practice. https:// doi.org/10.1080/13814788.2017.1375091

Kristiawan, M., Ahmad, S., Tobari, T., \& Suhono, S. (2017). Desain Pembelajaran SMA Plus Negeri 2 Banyuasin III Berbasis Karakter Di Era Masyarakat Ekonomi ASEAN. Jurnal Iqra': Kajian Ilmu Pendidikan, 2(2), 403-432. https:// doi.org/10.25217/ji.v2i2.178

Kusuma, B. N., Santoso, D. B., Shaddiq, S., Wijaya, F. D., \& Ardiyanto, I. (2016). An Optimal Design of Solar Water Pump System with Considering Cost and Effectiveness: Indonesian Perspective.Google Scholar

Ponidi, P., Waziana, W., Kristina, M., \& Gumanti, M. (2020). Model of Utilizing Discovery Learning to Improve Mathematical Learning Achievements. Attractive: Innovative Education Journal, 2(1), 41-48. Google Scholar

Ramadhani, Suswanta, \& Shaddiq, S. (2021). E-Marketing of Village Tourism Development Strategy (Case Study in the Tourist Village Puncak Sosok). Journal of Robotics and Control ISSN, 2715(5072), 73. Google Scholar

Saputra, M. R. Y., Winarno, W. W., Henderi, H., \& Shaddiq, S. (2020). Evaluation of Maturity Level of the Electronic based Government System in the Department 
of Industry and Commerce of Banjar Regency. Journal of Robotics and Control (JRC), 1(5), 156-161. Google Scholar

Shaddiq, S. (2013). Wind Turbine Energy as Alternative Power Sources and Renewable Energy Environmental Friendly. Google Scholar

Shaddiq, S., Ahmad, F. Z., Juwito, A. K. H., \& Alfarobi, F. F. (2012). Implementasi micro-hydro sebagai sumber energi pembasmi hama. Googe Scholar

Shaddiq, S., Santoso, D. B., Alfarobi, F. $\quad$ F., \& Hadi, S. P. (2016). Optimal capacity and placement of distributed generation using metaheuristic optimization algorithm to reduce power losses in Bantul distribution system, Yogyakarta. In $20168^{\text {th }}$ International Conference on Information Technology and Electrical Engineering (ICITEE),(pp. 1-5). IEEE. Google Scholar

Shaddiq, S., Kusumastuti, D., Ahmad, F. Z. (2012). Microhydro Contributions as Troubleshooter and The Right Solution at The Energy Crisis when Natural Disaster. Google Scholar

Sanaky H. (2011).Media Pembelajaran: Buku Pegangan Wajib Guru Dan Dosen:Penerbit: Kaukaba, Yogyakarta; Cetakan: Pertama, Februari 2011. Google Scholar

Sanjaya, W. (2010). Strategi Pembelajaran Berorientasi Standar Proses Pendidikan. Jakarta: Kencana Google Scholar

Suhono, S., \& Sari, D. A. (2020). Developing Students' Worksheet Based Educational Comic for Eleventh Grade of Vocational High School Agriculture. Anglophile Journal, 1(1), 29-40. Google Scholar

Wagiono, F., Shaddiq, S., \& Syahidi, A. A. (2020). Pengembangan Pkn Di Era Generasi Millenial Berbantuan M-Learning (Mobile Learning) Pada Gadget Pembelajaran Berbasis Cooperative Learning Bermuatan Karakter. Edunesia: Jurnal Ilmiah Pendidikan, 1(3), 63-72. Google Scholar

Yunita, S. (2020). Meningkatkan Hasil Belajar Siswa pada Materi Transformasi Melalui Media Geogebra Kelas IX di SMP N 2 Banjit Way Kanan. Attractive: Innovative Education Journal, 2(2), 89-106. Google Scholar

Zaenal, A. (2012). Pengembangan Media Video Pembelajaran IPA tentang Kemagnetan pada kelas IX SMPN 1 Mojowarno Jombang. Tesis. Google Scholar

Copyright Holder :

(c) Rizal, R., \& Misnasanti, M., Shaddiq, S., Ramdhani, R., \& Wagiono, F. (2020).

First Publication Right :

(c) IJoASER (International Journal on Advanced Science, Education, and Religion)

This article is under:

CC BY SA 